\title{
Oestrogen receptors in conjunctival malignant melanoma: Immunocytochemical study using formalin fixed paraffin wax sections
}

\author{
D A Paridaens, R A Alexander, J L Hungerford, A C E McCartney
}

\begin{abstract}
In a group of 15 women with conjunctival malignant melanoma six cases (40\%) were shown to have oestrogen receptor positivity using a monoclonal antibody to oestrogen receptor related antigen (ER-D5, Amersham RPN.710) on formalin fixed, paraffin wax sections. Receptors were also present in the epithelium of these six cases but not in controls and cases without ER-D5 positivity in their tumours. A subset of these aggressive, intractable unilateral tumours may therefore be amenable to hormone treatment.
\end{abstract}

Evidence suggests that endocrine factors may have a bearing on the biological behaviour of cutaneous malignant melanoma, but data have been conflictual. ${ }^{1-5}$ The contraceptive pill has been implicated in the growth of this tumour. ${ }^{6-8}$ Sadoff et al reported activation of melanoma after oestrogen administration in several patients and suggested a possible adverse effect of oestrogen. ${ }^{9}$ This was also evidenced by epidemiological studies showing a peak incidence of melanoma in women in the third and fifth decades, periods of high oestrogen activity. Experimental work with animal models has shown conflicting responses to hormonal manipulation. ${ }^{1011}$

The postulated hormone sensitivity of tumours arising from melanoblasts has led to the suggestion that malignant melanoma may be an endocrine dependent tumour, similar to carcinoma of the breast, kidney, and endometrium. ${ }^{9}$

Measurement of oestrogen receptors in carcinoma of the breast was seen as a major breakthrough in the selection of patients who would benefit from endocrine treatment. Oestrogen receptor analysis has improved the response rate from $30 \%$ in unselected patients to $60 \%$ in patients with oestrogen receptor positive breast cancer. ${ }^{12}$ Oestrogen receptor activity was found in $12-46 \%^{13-16}$ of cases of cutaneous melanoma, but it was not age or gender specific. Reports of uveal melanomas and endocrine influences are rare. ${ }^{17-21}$ Seddon et al investigated seven patients whose uveal melanomas and choroid were potentially hormonally responsive for the presence of oestrogen receptors, but specific oestrogen binding was not found. ${ }^{21}$

To our knowledge, possible hormone sensitivity of conjunctival melanoma has not been reported previously. Clinical observations of an extremely virulent and fulminant course of conjunctival melanoma in several women of child-bearing age led us to the hypothesis that at least a subset of conjunctival melanomas may be endocrine dependent. A recent immunocytochemical study on human conjunctiva of pre- and post-menopausal women and men did not show evidence of oestrogen and progesterone receptors on cells of the ocular surface. $^{22}$

Although commercially available monoclonal antibodies to the oestrogen receptor were originally marketed for use on frozen sections, they have been successfully applied to formalin fixed, paraffin wax embedded tissue. ${ }^{23-25}$ This rapid, semiquantitative immunocytochemical receptor analysis requires little tissue, is inexpensive and uncomplicated, and shows good correlation with standard chemical assays, as well as clinical responsiveness to endocrine treatment. ${ }^{26}$ This technique has permitted retro-

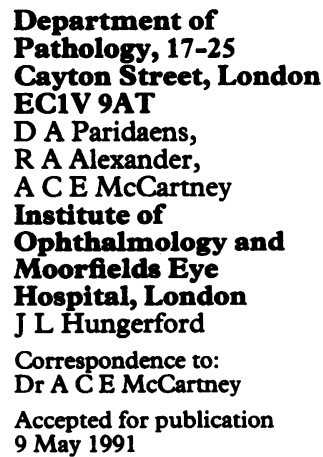

Table Pathological and immunocytochemical data on 15 women with conjunctival malignant melanoma

\begin{tabular}{|c|c|c|c|c|c|}
\hline Case No & $\begin{array}{l}\text { Age and year } \\
\text { at diagnosis }\end{array}$ & $\begin{array}{l}\text { Histological } \\
\text { origin }\end{array}$ & Cell type & $\begin{array}{l}\text { Conjunctival } \\
\text { epithelium score }\end{array}$ & $\begin{array}{l}\text { Conjunctival } \\
\text { melanoma score }\end{array}$ \\
\hline $\begin{array}{l}1 \\
2 \\
3 \\
4 \\
5 \\
6 \\
7 \\
8 \\
9 \\
10 \\
11 \\
12 \\
13 \\
14 \\
15\end{array}$ & $\begin{array}{l}26,1975 \\
20,1964 \\
37,1981 \\
24,1983 \\
64,1990 \\
26,1983 \\
31,1984 \\
47,1983 \\
42,1983 \\
39,1981 \\
36,1951 \\
46,1963 \\
30,1972 \\
49,1975 \\
18,1968\end{array}$ & $\begin{array}{l}\text { De novo } \\
\text { PAM } \\
\text { De novo } \\
\text { PAM } \\
\text { PAM } \\
\text { PAM } \\
\text { PAM } \\
\text { PAM } \\
\text { Naevus } \\
\text { PAM } \\
\text { PAM } \\
\text { De novo } \\
\text { Naevus } \\
\text { PAM } \\
\text { Naevus }\end{array}$ & $\begin{array}{l}E>S \\
E=S \\
E>S \\
E=S \\
E \\
E>S \\
E \\
E>S \\
E<S \\
E<S \\
E=S \\
E>S \\
E \\
E S S\end{array}$ & $\begin{array}{l}0 \\
0 \\
0 \\
0 \\
0 \\
9(3 \times 3) \\
9(3 \times 3) \\
0 \\
0 \\
9(3 \times 3) \\
2(2 \times 1) \\
2(2 \times 1) \\
0 \\
0 \\
1(1 \times 1)\end{array}$ & $\begin{array}{l}0 \\
0 \\
0 \\
0 \\
0 \\
6(2 \times 3) \\
2(2 \times 1) \\
0 \\
0 \\
2(1 \times 2) \\
4(2 \times 2) \\
1(1 \times 1) \\
0 \\
0 \\
1(1 \times 1)\end{array}$ \\
\hline
\end{tabular}




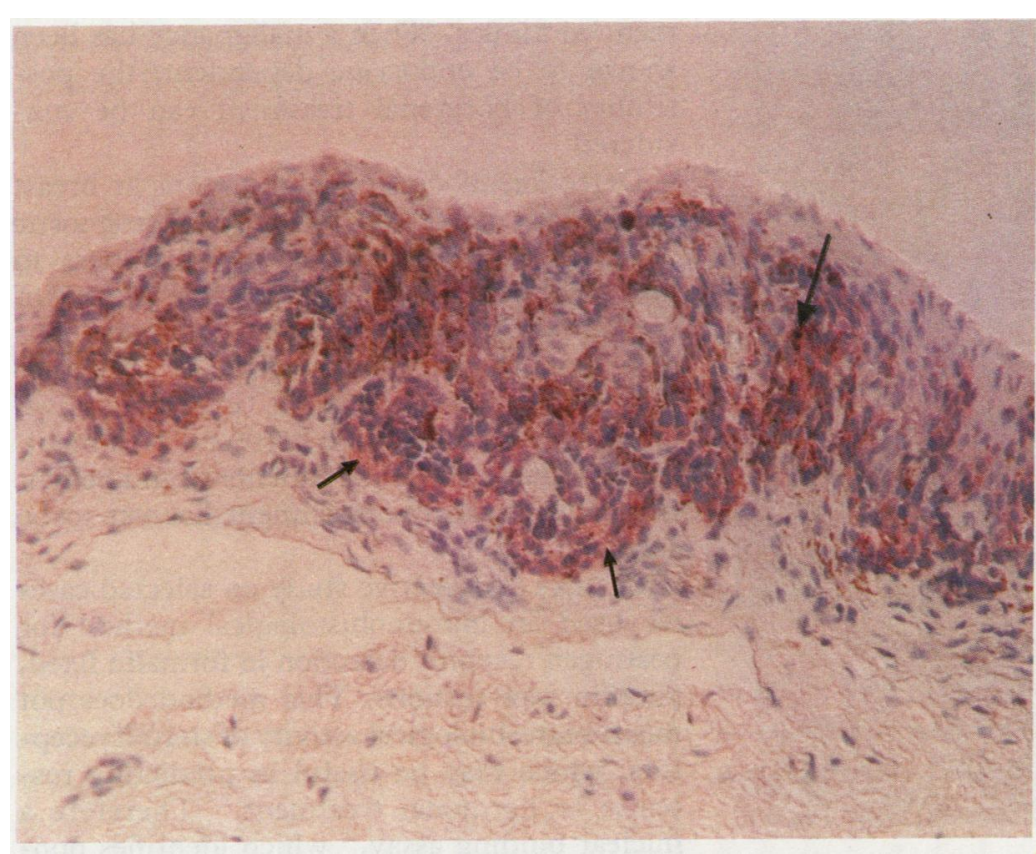

Figure 1 Malignant melanoma of the conunctiva arising in association with primary acquired melanosis with atypia in a 36 year old woman (case 11). Note the presence of dark-brown melanin (large arrow) and the diffuse intracellular red staining of oestrogen receptors (small arrows) (ER-DS).

spective studies of routinely processed histological material.

We selected a group of 15 predominantly premenopausal women with histologically confirmed conjunctival melanoma for assessment of oestrogen receptor response. The purpose of this retrospective study was to determine whether conjunctival malignant melanoma is oestrogen dependent.

\section{Methods}

Records of women with conjunctival malignant melanoma treated at Moorfields Eye Hospital were identified through a central cancer registry maintained by the cancer follow up secretary. Records dating from 1949 to 1990 were reviewed. Predominantly young women were selected, including those whose disease showed

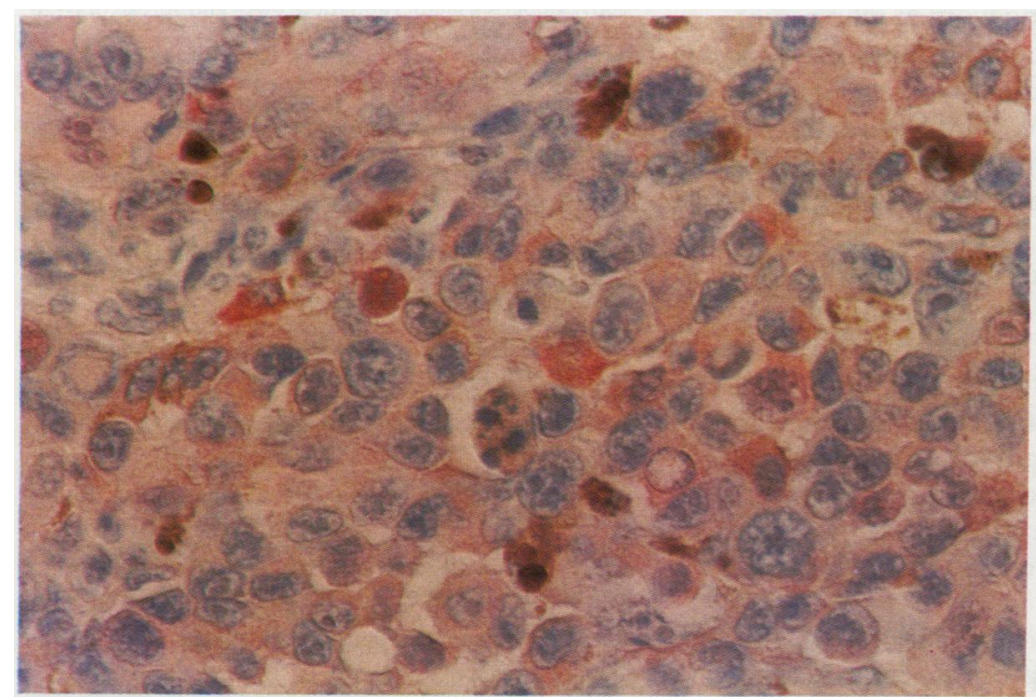

Figure 2 Epithelioid malignant melanoma of the conjunctiva in a 31 year old woman (case 7). The intensity and distribution of the red staining of oestrogen receptors varies within the specimen (ER-D5). a fulminant course. The group of 15 women included one postmenopausal woman and one with a documented history of pregnancy and conjunctival melanoma. In all cases the diagnosis of conjunctival malignant melanoma was verified histologically.

The formalin fixed, paraffin wax embedded biopsy specimens of the selected group of patients were dewaxed, hydrated, and immunostained using a mouse monoclonal antibody to oestrogen receptor related antigen (ER-D5, Amersham RPN.710) and a standard peroxidase-antiperoxidase method utilising immunochemicals from DAKO. ER-D5 recognises a 29 kilodalton non-hormone binding protein associated with the oestrogen receptor which has a cytoplasmic location rather than the nuclear locus of the oestradiol binding unit. ${ }^{27}$ The 29 kilodalton antigen is specific to mean, and present only in oestrogen receptor positive tissues.

Sections of human endometrium were used as known positive controls for ER-D5. Negative controls were performed by substituting the appropriate non-immune serum for the primary antibody. Normal conjunctival tissue specimens of a group of 10 gender matched patients were immunostained to assess oestrogen receptor content in women without conjunctival disease. All stainings were repeated at least once. Specimens of the patients group were also stained with haematoxylin and eosin, anti-S100 (DAKO), and anti-wide spectrum keratins (Z622, DAKO). A semiquantitative assessment of the staining results was made by two observers according to the intensity of the staining and the percentage of cells stained..$^{25} \mathrm{~A}$ scale of $1-3$ was used for each of these components. These figures were multiplied by each other, and the final score was expressed as follows: negative (grade -;score 0), weakly positive (grade + ;score 1-3), moderately positive (grade ++ ;score 4-6), and strongly positive (grade +++ ;score $>6$ ).

\section{Results}

The pathological data and the staining results are summarised in the table. Using the ER-D5 monoclonal antibody and the peroxidaseantiperoxidase (PAP) detection system, oestrogen receptors could be detected in both conjunctival melanoma and epithelial cells in six of 15 cases ( $40 \%$ ) (figs 1 and 2 ). The staining was restricted to the cytoplasm, the location of the non-hormone binding protein associated with the oestrogen receptor. The oestrogen receptor specific immunostaining in the endometrium of positive controls (fig 3) was localised to the paranuclear cytosol; there was a more diffuse cytoplasmic distribution in the conjunctival tumours.

Heterogeneity of the staining in both distribution and intensity was observed (figs 2 and 3 ). None of the omission controls showed positive immunostaining of conjunctival melanoma or epithelium. The conjunctival epithelium of 10 control specimens of unaffected conjunctiva showed no evidence of oestro- 


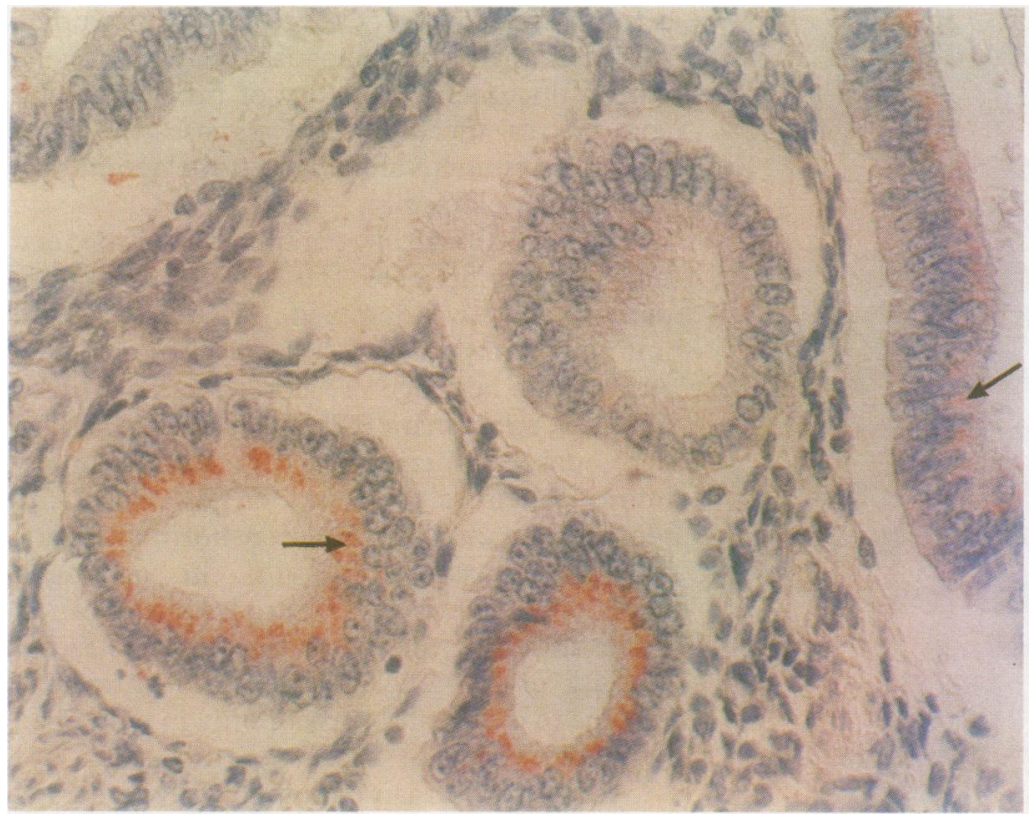

Figure 3 Control human uterine tissue showing the presence of oestrogen receptors (arrows) in the paranuclear cytosol of the duct cells. Note the heterogeneity of the red staining (ER-D5) ment continues. When a malignancy has been shown to be endocrine dependent, the possibility of hormonal treatment can be considered.

Detection of oestrogen receptors in breast carcinoma defines a favourable prognostic group with a predictable responsiveness to hormonal treatment. ${ }^{26}$ The possible efficacy of the anti-oestrogen, tamoxifen, in cutaneous melanoma remains controversial. ${ }^{28}{ }^{29}$ Whether oestrogen receptor content in conjunctival melanoma correlates with hormonal treatment, and whether a subset of patients would benefit from this alternative treatment has yet to be assessed.

In this retrospective study on selected cases we used an immunohistological method for oestrogen receptor detection in formalin fixed, paraffin wax sections. This method does not measure the biological activity of steroid receptors, which may be useful in predicting response to hormonal treatment. ${ }^{22}$ Therefore a nuclear binding assay, ${ }^{30}$ which identifies nonfunctional receptors, may be more appropriate.

Dr Dion Paridaens was supported by grants from Foundations "Stichting Bevordering van de Gezondheidszorg", "Stichting De Drie Lichten", and "Stichting Rens-Holle", The Netherlands. This study was supported by grant $91 / 5$ from Moorfields Eye Hospital, London. connective tissue and erythrocytes was noted, which was also present in negative controls, but the risk of false positive and false negative results was minimised by repeating the staining with similar and different dilutions of the primary antibody.

\section{Discussion}

The results of the present study indicate that malignant melanoma of the conjunctiva may be oestrogen dependent. Using the monoclonal antibody ER-DS, oestrogen receptors were detected in varying intensities in formalin fixed, paraffin wax sections of conjunctival melanoma. In the selected 15 cases six $(40 \%)$ were positive on immunostaining. We expect this percentage would be lower in a general population of conjunctival melanomas as the selection consisted of predominantly young women who might be more sensitive to hormonal influences. The percentage of cells stained showed no correlation with tumour cell type. The heterogeneity of the tumours was shown by the finding of a variable number of receptor negative cells in every positive case.

Another interesting observation was the oestrogen receptor positivity of conjunctival epithelial cells adjacent to positive staining melanomas. In our control group and in a previous study ${ }^{22}$ conjunctival epithelium was oestrogen receptor negative. Conjunctival melanoma is a unilateral disease, but it would be interesting to examine these cases for the presence of oestrogen receptors in the contralateral conjunctiva.

What are the clinical implications of the finding of oestrogen receptors in conjunctival malignant melanoma? As the management of this neoplasm remains problematic the current search for alternative or supplementary treat-
1 Pack GT, Scharnagel IM. The prognosis for malignant melanoma in the pregnant woman. Cancer 1951;4:324-34. 2 Byrd BF, McGanity WJ. The effect of pregnancy on the clinical course of malignant melanoma. South Med J 1954;47:196-200.

3 George PA, Fortner JG, Pack GT. Melanoma with pregnancy. Cancer 1960;13:854-9.

4 White LP, Linden G, Breslow L, Harzfeld L. Studies on melanoma. The effect of pregnancy on survival in human melanoma. JAMA 1961;177:235-8.

5 Shaw HM, Milton GW, Farago G, McCarthy WH. Endocrine influences on survival from malignant melanoma. Cancer 1978;42:669-77.

6 Ellerbroek WC. Oral contraceptives and malignant melanoma. JAMA 1968;206:649.

7 Lerner HG, Nordlund JJ, Kirkwood JM. Effects of oral contraceptives and pregnancy on melanomas. $N$ Engl $J$ Med 1979;301:47.

8 Stevens RG, Lee JAH, Moolgavkar SH. No association between oral contraceptives and malignant melanomas. $N$ Engl J Med 1980;302:966.

9 Sadoff $\mathrm{L}$, Winkley J, Tyson S. Is malignant melanoma an endocrine dependent tumour? The possible adverse effect of estrogen. Oncology 1973;27:244-57.

10 Proctor JW, Avelair RG, Stokowski L. Brief communicamelanoma. JNCI 1976;57:1197-8.

11 Lopez RE, Bhakoo H, Paolini NS, Rosen F, Holyoke ED, Goldrosen MH. Effect of estrogen on the growth of B-16 melanoma. Surgical Forum 1978;29:153-4.

2 Howanitz JH. Hormone receptors and breast cancer. Hum

13 Creagan ET, Ingle JN, Woods JE, Pritchard DJ, Jiang N. Estrogen receptors in patients with malignant melanoma. Cancer 1980;46:1785-6.

14 McCarty KS, Wortman J, Stowers S, Lubahn D, McCarty KS Sr, Seigler HF. Sex steroid receptor analysis in human melanoma. Cancer 1980;46:1463-70.

15 Chaudhuri PK, Walker MJ, Briele HA, Beattie CW, Das Gupta TK. Incidence of estrogen receptors in benign nevi therapy of surgically non-resectable malignant melanoma. 1978;19:139.

17 Siegel R, Amslie WH. Malignant ocular melanoma during pregnancy. JAMA 1963;185:542-3.

8 Borner R, Goder G. Melanoblastom der Uvea und SchwanFrenkel M, Klein HZ. Malignant melanoma of the choroid in pregnancy. Am J Ophthalmol 1966;62:910-13.

20 Reese AB. Tumors of the eye. 2nd edn. Hagerstown: Harper Ference III $M$. Uveal melanomas presenting during pregnancy and the investigation of oestrogen receptors in melanomas. Br J Ophthalmol 1982;66:695-704.

22 Gans LA, Lee SF, Lemp MA, Pepose JS. Estrogen and tion: Endocrine factors and the growth and spread of B-16 Pathol 1981;12:1057-9.

16 Fisher RI, Neifeld JP, Lippman ME. Diethylstilbestrol gerschaft. Klin Monatsbl Augenheilkd 1966;149:684-93. and Row, 1963, 366-70.

21 Seddon JM, MacLaughlin DT, Albert DM, Gragoudas ES, 
progesterone receptors and human conjunctiva. Am J Ophthalmol 1990;109:474-7.

23 Skovgaard Poulsen H, Ozzello L, King WJ, Greene GI. The use of monoclonal antibodies to estrogen receptors (ER) for immunoperoxidase detection of ER in paraffin sections of human breast cancer tissue. $J$ Histochem Sections of human breast

24 Shimada A, Kimura S, Abe K, et al. Immunocytochemical staining of estrogen receptor in paraffin sections of human breast cancer by use of monoclonal antibody: comparison with that in frozen sections. Proc Natl Acad Sci USA 1985;82:4803-7.

25 Shousha S, Coady AT, Stamp T, James KR, AlaghbandZadeh J. Oestrogen receptors in mucinous carcinoma of the breast: an immunohistological study using paraffin wax sections. J Clin Pathol 1989;42.902-5.

26 Wold LE. Immunohistochemical localization of estrogen receptors with monoclonal antibodies. In: Mark $\mathbf{R}$ Wick, GP Siegal, eds. Monoclonal antibodies in diagnostic immunohistochemistry. Marcel Dekker, Inc., New York: Marcel Dekker, 1988: 367-82.

27 Coffer AI. Immunoradiometric studies with monoclonal antibody against component related to human estrogen antibody against component related

28 Karakousis CP, Lopez RE, Bhakoo HS. Estrogen and progesterone receptors and tamoxifen in malignant melanoma. Cancer Treat Rep 1980;64:819-27.

29 Creagin ET, Ingle JN, Green SJ, et al. Phase II study of high dose tamoxifen in patients with disseminated malignant melanoma. Cancer 1982;49:1353-4.

30 Spelsberg TC, Graham ML, Berg NJ, et al. A nuclear binding assay to assess the biological activity of steroid receptors with use of intact cells from small samples of avian and human tissues. Clin Chem 1988;34:363.

\section{Eponyms in pathology ...}

GOLGI, Camillo (1844-1926) was born in Cortena, an alpine village in northern Italy. The son of a distinguished local doctor, he followed the family tradition and studied medicine in Pavia, qualifying in 1865. For several years he worked in the department of psychiatry where he wrote his first paper on the postmortem findings in a case of pellagra. In 1875 , after a three year spell as a physician in Milan, he was appointed Professor of histology at Pavia, and apart from a few months as professor of anatomy at Siena, he remained in Pavia, active in scholastic and civic life almost to the end. It was while in Milan that he pioneered the use of silver nitrate to stain nerve cells, a method described in 1873 after work by candlelight at a laboratory in his home. This marked the beginning of a great advance in the knowledge of the anatomy of the nervous system. Among his many papers on this subject, the principal one was "Studii sulla fina anatomia degli organi centrali de sistema nervoso", published in 1883, in which he described long and short axon nerve cells of the cerebral cortex (Golgi type 1 and 2 cells, respectively). Other structures which carry his name are the Golgi apparatus (1896) and Golgi corpuscles. In 1906 he shared the Nobel prize for medicine with Ramon-y-Cajal, despite their life-long rivalry. 